Original Russian Text (C 2019 N.E. Shevchenko, published in Forest Science Issues Vol. 2, No. 1, pp. $1-26$

DOI 10.31509/2658-607x-2019-2-2-1-18

\title{
ESSAY ON THE HISTORY OF STUDY OF FORESTS OF THE CENTRAL CISCAUCASIA
}

\author{
N.E. Shevchenko \\ Center for Forest Ecology and Productivity of the RAS \\ Profsoyuznaya st. 84/32 bldg. 14, Moscow, 117997, Russia \\ E-mail: neshevchenko@gmail.com \\ Received 19 February 2019
}

The article gives a brief overview of the history of study of forest flora and vegetation of the Central Ciscaucasia from the late 18th century till present. The entire history of the study of forests in this region can be divided into five periods. Each period has a particular degree and depth of study of forest flora and vegetation. The majority of the publications relates to individual areas where the vegetation cover was studied either as part of works covering larger regions or during narrowly focused studies. The long history of forest study in a region like the Central Ciscaucasia is of interest in the context of learning the history of scientific thought development in Russian botany.

Key words: Central Ciscaucasia, forest, flora, vegetation, study history, study period

The Central Ciscaucasia is the central part of North Caucasian plains and foothills. The region includes the Stavropol Upland, the Terek and Sunzha crests. Due to the complex terrain the orography-dependent differences in moisture are observed, and an altitudinal climatic zonality appears in some areas (the western part of the Sunzha crest, the Caucasian Mineral Waters region) (Gvozdetsky, 1957, 1963).

Currently, more than $80 \%$ of the forest area of the Central Ciscaucasia lie in the Stavropol Upland and the Terek and Sunzha crest (Shevchenko, Viktorov, 2014). Forests are formed by oak-hornbeam-ash and beech-oak-hornbeam communities with an admixture of the field maple (Acer campestre L.), Norway maple (A. platanoides L.), field elm (Ulmus minor Mill.), white poplar (Populus alba L.), cherry (Cerasus avium (L.) Moench.), Caucasian linden (Tilia begoniifolia Steven), Caucasian pear (Pyrus caucasica Fed.), common hawthorn (Crataegus monogyna Jacq.), blackthorn (Prunus spinosa L.) and others (Belous, Shevchenko, 2010; 2011; Shevchenko 2013; Shevchenko, Viktorov, 2014). In the gullies of the steppe rivers of the Kalaus Heights there are gully forests with predominant oak-hornbeam-ash and oak-ash communities. Oak-poplar and oak-elm-ash communities are common in the floodplains of the Kuban, Terek, Sunzha, Baksan and Kuma rivers (Shevchenko, Belous, 2007; Shevchenko, 2013). 
The objective of this study is to review the history of flora and vegetation study in the Central Ciscaucasia forests on the basis of literature-based data.

\section{RESULTS AND DISCUSSION}

The long history of studying the flora and vegetation of the Central Ciscaucasia forests is inextricably intertwined with the study of the Caucasus as a whole and dates back about 250 years. The entire period of botanical and geobotanical studies which someway or other deal with the area of interest can be divided into five main periods.

The first period (1771-1809) was marked by early expeditions of the St. Petersburg Academy of Sciences. The early period is associated with the names of famous botanists J.A. Güldenstädt (1787-1791), S.G. Gmelin (1784), P.S. Pallas (1789), and Ch.Ch. Steven (1809). Most routes of these expeditions merely touched the territory of the Central Ciscaucasia; the research was focused on studying the flora of the oldest Russia health resort, i. e. the Caucasian Mineral Waters region. Despite the general descriptive nature of the research, the obtained scientific materials formed the basis of knowledge about the nature of this region.

The small report on the forests of the Caucasian Mineral Waters by J.A. Güldenstädt "About Beshtau mountains or Pyatigorye" published in the collection "The latest geographical and historical information about the Caucasus" (Bronevsky, 1823) is of particular interest. This material is one of the first mentions of the forests of the Pyatigorye region with the enclosed brief listing of the flora of Mount Beshtau forest consisting of 54 plant species. J.A. Güldenstädt gives a brief overview of the forests of Mount Beshtau: "...making my way to the top of the mountain, the forest was markedly reducing and shrubs were gradually replacing it. Before I reached its naked summit,I noticed Pontic Azalea to be the most common of all plants... Other types of trees and plants are seen across the area of Mount Beshtau... The forest stretches beyond the foothill of Mount Beshtau in different directions, much further to the North, even reaching the plains, but in the East it is ends near Mashuk Mountain..." (Bronevsky, 1823. P. 361).

In 1773, J.P. Falk made an expedition to the Caucasus across the Terek and Sunzha crest. In his reports on the nature of the region he describes the species composition of the forests of the crest: "...elm, yew, hornbeam, barberry, pear, apple and plum species grow in the mountains near Terek..." (Falk, 1824. P. 227). Unfortunately, this report gives very little information about the forests of the region, at the same time it is one of the first references to the foothill forests of the Terek and Sunzha crest, and is in our opinion worth noting.

In 1793, an expedition under the leadership of P.S. Pallas was sent to the Caucasus to update and edit the data collected by J.A. Güldenstädt. The route passed through the mountains of Beshtau, Mashuk, the city of Kislovodsk, Georgievsk and the valley of the Baksan River. One of 
Pallas's descriptions is an essay on the forests of Mount Beshtau, listing 53 species of plants. In his notes, he writes that "... the forest on Beshtau is not evenly spread along the foothill of the mountain. Towards the East, it goes uninterrupted to Mashuk Mountain; to the North it reaches the foothill of the neighbouring mountains. Zheleznaya and Zmeyka mountains are also heavily forested..." (Pallas, 1789. P. 86).

In the period from 1800 to 1803 , Ch.Ch. Steven made an expedition across the North Caucasus. While travelling, he made notes on flora and collected a large herbarium. Ch.Ch. Steven was the first to describe such species as Colchicum umbrosum Stev., Dictamnus gymnostylis Stev., Ornithogalum arcuatum Stev. (Locus classicus, Mount Beshtau) in the forests of the Central Ciscaucasia (Steven, 1809).

The second period (1810-1895) contributed to the accumulation of knowledge about the flora of the region as well as to the collection of extensive herbarium material and the publication of floristic reports. Most expeditions were mainly observational and focused on the nature and population of the region. This period is associated with the names of F.M. von Bieberstein (1819), C. Koch (1849), A. Becker (1868), P.N. Muromtsev (1872), A.P. Overin (1875), A. Riesenkampf (1881-1882; 1882; 1883; 1904), A.P. Norman, (1881), I.Ya. Akinfiev (1893; 1894a; 18946; 1897; 1898), S. Sommier and E. Levier (1900). Currently, the herbarium material collected by them is the oldest documented source of information about the flora of the region and this information is cited in various floristic reports.

One of the important works of this period is the paper on the Crimean-Caucasian flora by F.M. von Bieberstein (Bieberstein, 1819) where the author gives information on nearly 2.300 plant species classified according to the Linnaean system. On the basis of collections made in the forests of the Central Ciscaucasia the author describes four new plant species: Lilium monadelphum M. Bieb. (Locus classicus Mount Beshtau), Euonymus nana M. Bieb. (Locus classicus Mount Beshtau), Hablitzia tamnoides M. Bieb. and Physochlaina orientalis M. Bieb. (Bieberstein, 1819).

In 1875, A.P. Overin published "The List of Pyatigorye Flora" consisting of ca. 800 species including 343 species of forest flora, with the extensive herbarium material (Overin, 1875). The report of A.P. Overin on flora of Pyatigorsk is most likely the first floristic report for the region of the Caucasian Mineral Waters.

In the second half of the 19th century A.P. Norman, an apothecary, collected a herbarium of the flora in the vicinity of the city of Stavropol, the valley of the Kuma River and the deserts of the the Kuma river region. After his death in 1913 M.V. Brzhezitzky and P.I. Nagorny published the "Florula Stavropolensis" collection with a list of 1,016 plant species. The herbarium collected by A.P. Norman is of great value for the study of forest flora in the region because it is the oldest one and includes many plant species of the Stavropol Heights forests, i. e. Archiyereysky, 
Tamansky, Chlinsky, Krugly, Temny forests and of Russkaya lesnaya dacha. Unfortunately, herbarium collection made by A.P. Norman was not followed by any further studies of the regional flora and vegetation. The majority of plants he collected were later classified by J.Th. Schmalhausen and partially by V.I. Lipsky. On top of that, the collections of A.P. Norman were random and only included 42 species of forest flora (Norman, 1881).

I.Ya. Akinfiev was exploring the flora of the Central Ciscaucasia from 1881 to 1898. Beside floristic collections, the author made notes on the ecology of forest communities of Mount Beshtau and their association with various forms of terrain: "... beech, hornbeam and linden are common throughout the shaded slopes, while oak, ash, maple, elm and other Ulmus species grow on the southern slopes" (Akinfiev, 1894b. P. 201). These reports are interesting in so far as they are the first attempts to explore the ecological patterns of location of forests of Mount Beshtau.

The third period (1898-1945) began with the first geobotanical reports on the territory of the Central Ciscaucasia, including those on forest vegetation. The first data on forest vegetation appeared in the works of V.V. Markovich (1898), V.I. Lipsky (1891; 1894; 1899), G. Shiryaev (1904), I.V. Novopokrovsky (1906), G. Stepunin (1914), W. Koch (1925) and others. Despite the fact that in many regions of the Russian Empire and later in the USSR forest typological studies flourished (Morozov, 1917; Pogrebnyak, 1928, etc.), forests of the Central Ciscaucasia were considered mainly as an object of floral studies.

The first geobotanical (Novopokrovsky, 1906; Bush, 1930; 1935; 1937; Kuznetsov, Bush and Fomin, 1901-1916, etc.) and floristic maps (Lipsky, 1899, etc.) of the region appeared, the issues of reforestation (Markovich, 1898; Stepunin, 1914; Rogovsky, 1928, etc.) were largely debated.

The monograph by V.V. Markovich "In the forests of Ichkeria - a forest ranger's memories of the Chechen forest" (1898) is the first paper to give practical recommendations on the protection and regeneration of forests of the Central Ciscaucasia, forest protection legislation and personal memoirs of the author are included. Botanical aspects form a small fraction of the work and include only a list of the main forest-forming tree species and their possible practical applications. This paper is of great value in terms of studying the history of forest management in the region (Markovich, 1898).

The monumental work of the famous researcher of the Caucasian flora V.I. Lipsky, "Flora of the Caucasus" (1899), containing a list of 4,430 plant species with their geography was published in the late 19th century. One more focus of the paper is the history of the study of regional flora with a list of literature and a brief analysis of each paper (Lipsky, 1899).

The article by G.I. Radde "The main features of the plant world in the Caucasus" (1901) gives a review of the patterns of vegetation distribution in the Caucasus region including the Central 
Ciscaucasia. It was noted that "...the valley of Baksan and Malka is abundant in willows with black poplars, aspen, crippled oaks in between... " (Radde, 1901. P. 112).

The "Proceedings of the Society of Naturalists of Kazan University" collection, containing a large article on the vegetation of the southern slopes of Mashuk Mountain by G. Shiryaev, titled "Vegetation of Mashuk Mountain" was published in 1904. The paper contains findings of a floristic study of the southern slope of Mashuk Mountain; it is noted that all forests of Mashuk Mountain are secondary (Shiryaev, 1904).

In this period of research it is also necessary to mention the article by G. Stepunin "Forests of the Stavropol Upland" (1914). The final version of the article was never published because of the revolution. This article gives some recommendations on economic use of the woods and on geography of the Stavropol Upland.

In addition to these publications on the flora and vegetation of the region, a number of summary reports was also published in this research period, someway or other concerning the forest flora of the Central Ciscaucasia. Those are such works as "Flora Caucasica Critica..." (Kuznetsov, Bush and Fomin, 1901-1916); "Vegetation of the Stavropol Krai" (Novopokrovsky, 1906); "List of plants of the North Caucasus and Dagestan" (Flerov, 1938); "A botanical and geographical sketch of the Caucasus" (Bush, 1935); "List of plants collected in the vicinity of stanitsa Naurskaya, Terek region (Razdorsky, 1913); "Vegetation of Kabarda" (Chernetskaya, Vinogradov, 1926), etc.

The fourth period (1946-1987) began with the publication of the first forest typological works on the forests of the Central Ciscaucasia and the North Caucasus; floristic, florogenetic and geobotanical studies of the Caucasus were continued. This period is associated with the names of T.B. Vernander (1946), A.A. Klopov (1952; 1960), N.N. Tumadzhanov (1961), V.N. Kononov (1960; 1964; 1968; 1971; 1976), S.P. Ganzha (1968), B.F. Ostapenko (1974), V.G. Gnilovsky (1971; 1976) and others.

Unlike the works of the previous periods, these ones became comprehensive studies of the forests of the region were carried out. One of the top priorities was the economic and conservation value of forests as well as measures for their regeneration. Most publications somehow related to the forests of the region were made as review articles without detailed descriptions of forest communities. Besides, there was almost no information about the state of forest communities of the Terek-Sunzha crest and floodplain forests of the foothills of the Central Ciscaucasia, apart from some solitary floristic notes.

The article by T.B. Vernander "Vegetation of the urban forest of Mount Beshtau" (1946) became one of the first forest typological papers on Ciscaucasian forests. The paper not only gives floristic descriptions of the forests of Mount Beshtau, but also contains information on the history of exploration of these forests. T.B. Vernander distinguishes 4 types (beech, ash, hornbeam and 
oak) and 12 cycles of forest type of the urban forest of Mount Beshtau. One of the limitations of this work is that it is an overview, lacking specific geobotanical descriptions or methodological features of distinguishing between forest types and cycles.

At this period V.N. Kononov published his articles on the study of individual small forest areas of the region, i. e. Russky, Kazenny forests, forests of the heads of the Yegorlyk and Tomuzlovka rivers $(1960 ; 1964$; etc.), which are small floristic reports without geobotanical descriptions.

In the context of studying the history of reclamation and restoration of the forests of the Stavropol Upland the article by A.A. Klopov "Forests of the Stavropol Krai" (1952) is of great interest. It provides historical facts about reforestation in the Stavropol Krai from the late 19th to the mid-20th century.

In 1968, the article by S.P. Ganzha "Forest types of the Stavropol Upland" was published. Depending on the dominance of the main forest-forming species for the Stavropol Upland, the author distinguishes five types of forests (beech, oak, maple, hornbeam and ash) (Ganzha, 1968).

The monograph by B.F. Ostapenko "Types of forests of the Stavropol Krai" (1974) deserves special attention. It provides six main types of forest within the boundaries of the modern Stavropol Krai and the Karachay-Cherkessia Republic: oak, beech, dark coniferous, pine, floodplain and forests of the upper boundary of the stand spread (Ostapenko, 1974). Of all the papers dealing with the forests of the region, this monograph is the most interesting one from the forest typological point of view. In addition to describing the types of forest, the paper lists economic groups and logging principles of forests. The monograph lacks comprehensive assessment and comparative description of forest types of the region.

An outstanding work on the history of forest management and forest area dynamics in the Ciscaucasia is the article by V.G. Gnilovsky "Forests of the Stavropol Upland according to historical and geographical data" (1971), "New data on forest maps of the Stavropol Krai in the early 19th century" (1976). The author analyzes old maps of the Caucasus. The findings of his research make it possible to assess the dynamics of the composition of the main forest-forming species, predominantly of the forests in the vicinity of Stavropol. These articles provide a list of inventory numbers of old maps of the region and their storage data, making it much easier to find them for more detailed study.

In addition to the above works, there was a number of publications in this period someway or other concerning the forests of the Central Ciscaucasia: "Flora of Kabarda" (Kos, Demishev, 1951)"; "The condition of stands of the forest area of Mount Beshtau" (Bondarenko, 1958); "Development of forest crops on the green slopes in the area of the Caucasian Mineral Waters" (Demyanov, 1964); "The guide to higher plants of North-West Caucasus and Ciscaucasia" 
(Kosenko, 1970); "Vegetation of Checheno-Ingushetia" (Galushko, 1975); "Ecology of herbaceous plants of forest-steppe oak forests" (Goryshina, 1975); "To the research of the floristic composition of the Stavropol Upland forests" (Grantseeva, 1976); "Flora of the North Caucasus" (Galushko, 1978-1980); "Vegetation of the North Caucasus and its natural forage lands" (Shiffers, 1953); "Forest resources of Kabardino-Balkaria" (Nechaev, 1960); "Catalogue of wild plants of the Stavropol Krai" (Tanfiliev, Kononov, 1987) etc.

The fifth period (from 1988 till present) is marked by the transition to an in-depth study of local flora and vegetation, analysis and generalization of materials from previous periods. One of the top focuses is research into the state of threatened and endangered plant species which is associated with the publication of regional Endangered Species Lists (Red Books) (Endangered Species List of the Republic of North Ossetia-Alania, 1999; Endangered Species List of the Kabardino-Balkarian Republic, 2000; Endangered Species List of the Stavropol Krai, 2002; Endangered Species List of the Republic of Ingushetia, 2007, and Endangered Species List of the Chechen Republic, 2008). Most of the works are aimed at taking inventory of the flora. Major reports such as "Brief listing of the flora of the Stavropol Krai" (Ivanov, 1997, 1998); "Brief listing of the flora of the Chechen Republic" (Umarov, Taysumov, 2011); "Brief listing of the vascular plant flora of the Caucasian Mineral Waters and neighbouring areas" (Mikheev, 2009) are published. A number of theses were devoted to the analysis of flora of certain floristic regions (Ivanov, 1998; Utenkova, 2001; Ivanov, 2004; Chimonina, 2004; Mikheev, 2009; Morozova, 2009, etc.) was defended. These papers analyze the flora of certain floristic areas without delineation of the forests; there are no descriptions of forest types or patterns of their distribution. Besides, the publication of a series of articles is continued on the study of flora of individual forest areas, updating of areas and description of the status of populations of threatened and endangered plant species (Gruchushkina-Sukhorukova et al., 1993; Belous, Dronov, 2005; Ivanov, 1990; Shevchenko, Belous, 2005; 2006; 2007a; 2007б; 2008, 2009; Shevchenko, 2007a; 2007б; 2008; 2009a; 2009б; 2011a; 2011б; Shevchenko N. E., Belous V. N., Ulanovsky, 2012; Doronin, Shevchenko, 2008; etc.).

In 2014 the "Brief listing of the flora of the Central Ciscaucasia forests" (Shevchenko, Belous, 2014) was published, which is a result of the successful candidate's thesis "Forests of the Central Ciscaucasia: floristic composition, vegetation and problems of their protection" (Shevchenko, 2013). The "Brief listing..." lists 746 species of vascular plants of forest flora and provides with ecological, chorological and phytosozological description of the se species.

Based on the materials of archival records, old forest maps and review of published papers, the article by N.E. Shevchenko "Dynamics of the area and measures of forest conservation of the Stavropol Governorate based on historical and geographical data from the late 17 th to the 
early 20th century" (Shevchenko, 2015) provides information on the area and measures of forest protection in the Stavropol Governorate (the Stavropol Upland). The role of the Stavropol Governorate Forest Protection Committee and certain provisions of the Forest Department in the conservation of forests in the region is outlined. Three main stages of artificial reforestation are described followed by the examples of individual works being of the greatest importance for the region. It was found that from the late 17th century to 1880 the forest area of the Stavropol Upland decreased by $40 \%$ due to active exploitation of the region and uncontrolled felling. From 1880 to 1917, successful reforestation resulted in the increase of the forest area in the governorate by $22 \%$.

In the period from 2012 to 2018, a series of articles on the analysis of the flora of the Central Ciscaucasia forests (Shevchenko, 2018), their forest typological composition (Shevchenko, Viktorov, 2014), spectrum of fertile forms of forest flora (Shevchenko, Godin, 2015) and the history of forest protection in the region (Shevchenko, 2012; 2011в; 2014) was published.

Therefore, the long history of studying the flora and vegetation of the Central Ciscaucasia forests, from the first expeditions of the St. Petersburg Academy of Sciences to the present time, made it possible to scrutiny the floristic composition and vegetation of forests in the region, the history of natural resource management and the dynamics of their area. Reviewing the materials on the history of forest studies in the region provides an opportunity to assess the promising lines of future research. These papers clearly lack deep research of the structural and functional organization of forest ecosystems aimed at increasing productivity and preserving forests' biodiversity in the arid climate of the region.

\section{ACKNOWLEDGEMENTS}

Materials of the study were collected by of state assignment "Methodical approaches to the assessment of the structural organization and functioning of forest ecosystems"№ AAAAA18-118052400130-7, results of the study were processed by supported Russian Science Foundation (project 16-17-10284).

\section{REFERENCES}

Akinfiev I.Ya., Flora Central `nogo Kavkaza. Ch.1. (Flora of the Central Caucasus. Part 1),

Trudy`obshhestva ispy`tatelej prirody ` pri Xar `kovskom un-te, 1894b, Issue 27, pp. 123-332.

Akinfiev I.Ya. Kavkaz. I., Botanicheskoe issledovanie Stavropol'skoj gubernii v 1889 g. Verxov'e Kalausa i Stavropol'skoe podnyatie (North Caucasus. I. Botanical research of the Stavropol province in 1889), Zapiski Kavkazskogo otdeleniya Russkogo geograficheskogo obshhestva, 1994a, Issue 10, pp. 65-79.

Akinfiev I.Ya., Novy`e i redko vstrechayushhiesya vidy Kavkazskoj flory, sobranny`e $v$ 1882-1891 gg. (New and rare species of Caucasian flora collected in 1882-1891), Zapiski Kavkazskogo otdeleniya Russkogo geograficheskogo obshhestva, 1893, Issue XV, pp. 1-24. 
Akinfiev I.Ya., Severny`j Kavkaz. II. Botanicheskoe issledovanie Kubano-Terskogo vodorazdela i E'l'brusa (North Caucasus II. Botanical study of the Kuban-Terek watershed and Elbrus), Trudy`Tiflisskogo botanicheskogo sada, 1898, 86 p.

Akinfiev I.Ya., Vesennyaya poezdka na Kavkaz v 1897 g. (Spring trip to the Caucasus in 1897), Estestvoznanie i geografiya, 1897, No 4, pp. 83-84.

Becker A. Reise nach dem Kaucasus, Bull. Soc. Imper. Naturalistes de Moscou, 1868, No 1, pp. 191.

Belous V.N., Dronov D.M., Proshloe i nastoyashhee bajrachny`x lesov reki Malaya Bujvola (The past and the present of the gloom forests of the Malaya Buyvola River), X nauchnoprakticheskaya konferenciya «E`kologo-kraevedcheskie problemy`Stavropol `ya, 2005, pp. 185-19.

Belous V.N., Shevchenko N.E., Lesny`e soobshhestva verxov`ev reki Egorly`k (Stavropol'skaya vozvy`shennost): istoriya i sovremennost (Forest communities of the upper reaches of the Egorlyk River (Stavropol Upland): history and modernity), Vestnik MGOU. Estestvenny`e nauki, 2010, No 4, pp. 67-76.

Belous V.N., Shevchenko N.E., Osobennosti korenny`x lesny`x soobshhestv Stavropol`skoj vozvy shennosti (na primere Russkogo lesa) (Features of indigenous forest communities of the Stavropol Upland (on the example of the Russian forest)), Vestnik MGOU. Estestvenny'e nauki, 2011, No 4, pp. 38-43.

Bieberstein F.M., Flora Taurico-Caucasica exhibens stripes phaenogamas in Chersoneso Taurica et regionibus Caucasicis sponte crescents, Charcoviae, 1819, Vol. 3, 654 p.

Bondarenko N.Ya., Sostoyanie nasazhdenij Beshtaugorskogo lesnogo massiva (State of stands of the Beshtaugorsky forest area), Sb. rabot po drevesnomu xozyajstvu Sev. Kavkaza, 1958. Vol. 3. pp. 87-102.

Bronevsky S.M., Izvestiya o Kavkaze. Chast 2 (News of the Caucasus. Part 2). Moscow: Typography S. Selivanovskago, 1823. 465 p.

Bush N.A., Botaniko-geograficheskij ocherk Kavkaza (Botanical and geographical sketch of the Caucasus). M.-L.: Publishing House of the Academy of Sciences of the USSR, 1935, 108 p.

Bush N.A., Obzor rabot po flore i rastitel nosti Kry`ma, Kavkaza i Zakavkazya s 1920 po 1929 (Review of works on the flora and vegetation of the Crimea, the Caucasus and Transcaucasia from 1920 to 1929), Zhurnal Russkogo botanicheskogo obshhestva, 1930, Vol. 14, pp. 335-364.

Bush N.F., Botanical studies of the Caucasus for 20 years of Soviet power, Nature, Leningrad, 1937, No 11, pp. 23-29.

Chernetskaya Z.S., Vinogradov S.I., Rastitel'nost' Kabardy (Vegetation of Kabarda), Voronezh, 1926. 32 p. 
Chimonina I.V., Flora Prikalausskogo floristicheskogo rajona (Central`noe Predkavkaz`e) $i$ eyo analiz (Flora of Prikalausky floristic region (Central Ciscaucasia) and its analysis), Stavropol, 2004, 221 p.

Demyanov V.P., Sozdanie lesny`x kul`tur na ozelenenny`x sklonax v zane Kavkazskix Mineral'ny $x \operatorname{Vod}$ (Creation of forest cultures on green slopes in the territory of the Caucasian Mineral Waters), Trudy`SKLOS, 1964, Issue VI, pp.135-156.

Falk I.P., Zapiski puteshestviya. Ot Peterburga do Tomska (Travel notes. From Petersburg to Tomsk), SPb., 1824, 446 p.

Flerov A.F., Spisok rastenij Severnogo Kavkaza i Dagestana (List of plants of the North Caucasus and Dagestan), Rostov-on-Don, 1938, 695 p.

Galushko A.I., Flora Severnogo Kavkaza (Flora of the North Caucasus), Rostov: Rostov State University, 1978-1980, Issue. 1-3, 327 p.

Galushko A.I., Rastitel'ny`j pokrov Checheno-Ingushetii (Vegetative cover of ChechenIngushetia), Grozny: Chechen-Ingush Prince. publishing house, 1975, 117 p.

Ganzha S.P., Tipy' lesa Stavropol'skoj vozvy`shennosti (Types of forest of the Stavropol Upland), Trudy`Xar`kovskogo s/x in-ta, 1968, Issue 72. pp. 258-268.

Gmelin S.G., Reise durch Russland zur Untersuchung der drei Natur-Reiche, Theil IV, St. Petersbourg, 1784, 304 p.

Gnilovskoy V.G., Lesa Stavropol`skoj vozvy`shennosti po istoriko-geograficheskim danny`m (Forests of the Stavropol Upland according to historical and geographical data), Materialy izucheniya Stavropol skogo kraya, 1971, Vol. 12-13, 109-136 p.

Gnilovskoy V.G., Novy`e danny`e o lesny`x kartax Stavropol ya nachala 19 veka (New data on forest maps of Stavropol early 19th century), Materialy po izucheniyu Stavropol skogo kraya, 1976, Issue 14, $380 \mathrm{p}$.

Goryshina T.K., E`kologiya travyanisty`x rastenij lesostepnoj dubravy` (Ecology of herbaceous plants of forest-steppe oak forest), Leningrad, 1975, 59 p.

Granceeva L.G., K izucheniyu floristicheskogo sostava lesov Stavropol skoj vozvy`shennosti (To study the floristic composition of forests of the Stavropol Upland), Flora Severnogo Kavkaza. 1976, Vol. 2, pp. 63-69.

Grechushkina-Sukhorukova L.A., Belous V.N., Isaenko T.N., K sovremennomu sostoyaniyu lesa Kruglen `kogo (To the modern state of Krugly’s forest), Sovremenny`e problemy` $e^{` k o l o g i i ~} i$ prirodopol zovaniya na Stavropol'e, 1993, pp. 28-30.

Guldenstandt I.A., Reisen surch Russland und im Kaukasischen Gebirge, herausgegeben von P.S. Pallas, St. Petersbourg, 1787-1791, Issue 1, 511 p.; Issue 2, 552 p. 
Gvozdetsky N.A., Fizicheskaya geografiya Kavkaza. Predkavkaz’e. Zakavkaz’e. (Physical geography of the Caucasus. Ciscaucasia. Transcaucasia), Moscow: Moscow State University Publishing House, 1957, Vol. III, 103 p.

Gvozdetsky N.A., Kavkaz (Caucasus). Moscow: State Publishing House of Geographic Literature, 1963, $260 \mathrm{p}$.

Ivanov A.A., Flora Stavropol'skix vy`sot $i$ eyo analiz (Flora of Stavropol Heights and its analysis), Stavropol, 2004, 224 p.

Ivanov A.L., Flora Predkavkazya i eyo genezis (Flora of Ciscaucasia and its genesis), Stavropol: Publishing House of SSU, 1998, 204 p.

Ivanov A.L., K oxrane redkix rastenij Stavropol'skoj vozvy`shennosti (To the protection of rare plants of the Stavropol Upland), Oxrana, obogashhenie, vosproizvodstvo $i$ ispol zovanie rastitel'ny`x resursov, 1990, pp. 318-320.

Ivanov A.L., Konspekt flory`Stavropolya (Abstract flora Stavropol), Stavropol: SSU Publishing House, 1997, 155 p.

Klopov A.A., Lesa Stavropol'skogo kraya (Forests of the Stavropol Territory), Materialy po izucheniyu Stavropol skogo kraya, 1952, Issue 4, pp. 35-42.

Klopov A.A., Lesorazvedenie na Stavropol'e (kratkij istoricheskij ocherk) (Forest culture in the Stavropol region (brief historical sketch)), Materialy` po izucheniyu Stavropol'skogo kraya, 1960, pp. 21-35.

Koch K., Beitrage zu einer Flora des Orientes, Linnaea, 1849, Issue XXII, pp. 597-752.

Koch W., Die Vegetationseinheiten der Linthebere unter Berucksichtigung der Verhaltnisse in der N.O. Schweiz, Jb. St. Gall. Naturw. Ges, 1925, No 61 (2), pp. 1-146.

Kononov V.N., Rastitel ’nost` $i$ konspekt flory`Stavropol`skoj vozvy`shennosti $i$ KumoMany chskoj vpadiny (Vegetation and summary of the flora of the Stavropol Upland and the KumoManych Depression), Chisinau, 1968, 53 p.

Kononov V.N., Rastitel'nost verxovij r. Tomuzlovki na Stavropol skoj vozvy`shennosti (Vegetation of the upper river. Tomuzlovki on the Stavropol Upland), Materialy po izucheniyu Stavropol 'skogo kraya. 1964. Issue 11. pp. 126-136.

Kononov V.N., Rastitel`nost`yugo-zapadnoj chasti Stavropol`skoj vozvy`shennosti (The vegetation of the southwestern part of the Stavropol Upland), Materialy po izucheniyu Stavropol skogo kraya, 1960, Vol. 10, pp. 172-202.

Kononov V.N., Redkie i ischezayushhie vidy`Stavropol'skoj flory` (Rare and endangered species of Stavropol flora), Trudy`Stavropol`skogo NIISX, 1976. Vol. 39, pp. 140-153. 
Kononov V.N., Stavropol`skoj vozvy`shennosti i eyo geograficheskie svyazi (Forest-steppe of the Stavropol Upland and its geographical links), Materialy po izucheniyu Stavropol skogo kraya, 1971, Vol. 12-13, pp. 97-108.

Kos Yu.I., Demishev K.S., Rastitelny`j mir Kabardy (Flora of Kabarda), Nalchik: Kabardian State Publishing House, 1951, pp. 147-150.

Kosenko I.S., Opredelitel vy`sshix rastenij Severo-Zapadnogo Kavkaza i Predkavkazya (The determinant of higher plants of the North-Western Caucasus and Ciscaucasia), M.: Kolos, 1970,614 p.

Krasnaya kniga Chechenskoj Respubliki (The Red Book of the Chechen Republic), Grozniy, 2008. 312 p.

Krasnaya kniga Ingushetii. Rasteniya $i$ zhivotnye (Red Book of Ingushetia. Plants and animals), Magas: Serdalo, 2007, 368 p.

Krasnaya kniga Kabardino-Balkarskoj Respubliki (The Red Book of the KabardinoBalkarian Republic), Nalchik: El-Fa Publishing House, 2000. 308 p.

Krasnaya kniga Respubliki Severnaya Osetiya - Alaniya. Redkie i naxodyashhiesya pod ugrozoj ischeznoveniya vidy rastenij $i$ zhivotny`x (The Red Book of the Republic of North Ossetia Alania. Rare and endangered species of plants and animals), Vladikavkaz: Project-Press, 1999. 248 p.

Krasnaya kniga Stavropol'skogo kraya (Red Book of the Stavropol Territory. Plants), Stavropol, 2002, $361 \mathrm{p}$.

Kuznetsov N.A., Bush N.A., Fomin A.V., Flora Caucasica Critica, 1901-1916. Materialy dlya flory`Kavkaza. Kriticheskoe sistematichesko-geograficheskoe issledovanie (Flora Caucasica Critica, 1901-1916. Materials for the flora of the Caucasus. Critical systematic geographical research), Yuriev: Type. Matissen, Part 1-4, Issue 1-9: Part I, Vol. 1, 247 p.; Part II, Vol.1, 43 p.; Part II, Issue 5, 32 p.; Part III, Issue 1, 256 p.; Part III, Issue 4, 758 p.; Part III, Issue 5, 48 p.; Part III, Issue 7, 112 p.; Part III, Issue 8, 48 p.; Part III, Issue 9, 384 p.; Part IV, Vol. 1, 590 p.; Part IV, Issue 2, 400 p.; Part IV, Vol. 3, 96 p.

Lipsky V.I., Flora Ciscaucasica. Ocherk rastitel'nosti Predkavkaz'ya (Flora Ciscaucasica. Essay on Vegetation of the Pre-Caucasus), Zapiski Kievskogo obshhestva estestvoispy tatelej, 1894, Issue 13, Vol. 1, pp. 209-288.

Lipsky V.I., Flora Kavkaza. Svod svedenij o flore Kavkaza za dvuxsotletnij period ego issledovaniya, nachinaya ot Turnefora $i$ konchaya XIX v. (Flora of the Caucasus. A compilation of information about the flora of the Caucasus for the two hundred year period of his research, beginning with the Tournefort and ending with the XIX century), Trudy Tiflisskogo Botanicheskogo sada, 1899, Issue. 4, $584 \mathrm{p}$. 
Lipsky V.I., Issledovanie Severnogo Kavkaza 1889-1890 gg. Predvaritel`ny jotchyot (The study of the North Caucasus in 1889-1890. Preliminary Report), Zapiski Kievskogo obshhestva estestvoispy`tatelej, 1891, pp. 23-61.

Markovich V.V., Lesa Ichkerii - vospominaniya lesnichego o lese (Forests of Ichkeria forestry memories of the forest), Tiflis: M. Sharadze and K., 1898, 96 p.

Mikheev A.D., Flora Kavkazskix Mineral`ny`x Vod i prilegayushhix territorii: analiz $i$ voprosy oxrany (Flora of the Caucasian Mineral Waters and adjacent territories: analysis and protection issues), SPb., 2009, 315 p.

Mikheev A.D., Konspekt flory`sosudisty`x rastenij rajona Kavkazskij Mineral`ny`x Vod i prilegayushhix territorij (Summary of the flora of vascular plants of the Caucasian Mineral Waters region and adjacent territories), Pyatigorsk, 2009, 51 p.

Morozov G.F., O tipologicheskom izuchenii lesov. Kostroma: Gubernskaya tipografiya (On the typological study of forests. Kostroma: Provincial Printing House), 1917, 157 p.

Morozova O.V., Flora Sredne-Kumskogo Floristicheskogo rajona (Central'noe Predkavkaz'e) i ee analiz (Flora of the Middle Kumsky Floristic region (Central Ciscaucasia) and its analysis), Stavropol, 2011, 221 p.

Muromtsev P.N., Zametki o flore Pyatigorskogo kraya (Notes on the flora of the Pyatigorsk Territory), Izvestiya Kavkazskogo otdeleniya Imperatorskogo Russkogo Geograficheskogo obshhva. SPb., 1872, Issue I.I, No 6, pp. 1-8.

Nechaev V.N., Lesny`e bogatstva Kabardino-Balkarii (Forest wealth of KabardinoBalkaria), Ordzhonikidze, 1960, 297 p.

Norman A.P., Florula Stavropolensis. Stavropol skaya flora (Florula Stavropolensis. Stavropol flora), Tiflis: Publishing House of the Stavropol Statistical Committee, 1881, pp. 1-61.

Novopokrovsky I.V., Botaniko-geograficheskie issledovaniya yugo-vostochnoj chasti Stavropol skoj gubernii $i$ smezhnoj chasti Terskoj oblasti (Botanical and geographical research of the southeastern part of the Stavropol province and the adjacent part of the Terek region), Zapiski Novorossijskogo obshh-va estestvoispy`tatelej, 1906, pp. 1-71.

Ostapenko B.F., Tipy lesov Stavropol'skogo kraya (Types of forests of the Stavropol Territory), Stavropol: Stavropol Book Publishing House, 1974, 234 p.

Overin A.P., Perechen`Pyatigorskoj flory (The list of Pyatigorsk flora), Bull. Soc. Imper. Des Naturalistes de Moscou, 1875, No 2, pp. 156-210.

Pallas P.S., Flora Rossica seu stirpium Imperii Rossici per Europam et Asiam indigenarum descriptines. Iussu et auspiciis Catharinae II Augustar, Edidit P.S. Pallas, 1789, Issue 1, 191 p. 
Pallas P.S., Flora Rossii. Opisanie rastenij Rossijskogo gosudarstva s ix izobrazheniem, na russkom yazy ke. Chast ${ }^{1}$ 1. (Flora of Russia. Description of plants of the Russian state with their image in Russian. Part 1), SPb., 1786, 204 p.

Pogrebnyak P.S., Lesorastitel'ny`e usloviya levoberezhnogo Poles ya (Forest growing conditions of left-bank Polesia), Trudy ро ору`ппоти lesnomu delu Ukrainy, 1928, Issue 10, pp. 4678.

Radde G.I., Osnovny'e cherty` rastitel'nogo mira na Kavkaze (The main features of the plant world in the Caucasus), Zapiski Kavkazskogo otdeleniya Russkogo geograficheskogo obshhestva, 1901, Issue 3, pp. 1-199.

Razdorsky V.F., Spisok rastenij, sobranny`x v okrestnostyax st. Naurskoj Terskoj oblasti (List of plants collected in the vicinity of Art. Naurskaya Terek region), Vestnik Tiflisskogo Botanicheskogo sada, 1913, Vol. 31, 22 p.

Rizenkampf A., Bolee redkie ili zamechatel`ny`e rasteniya Pyatigorskogo kraya (Rarer or Wonderful Plants of the Pyatigorsk Territory), Ezhegodnik Kavkazskogo Gornogo obshhestva. Pyatigorsk. Pyatigorsk, 1904, No 1, pp. 83-85.

Rizenkampf A., O nekotory`x osobennostyax Pyatigorskoj flory`Kavkazskix Mineral`ny`x Vod $i$ special no o martovskoj flore e togo rajona (On some features of the Pyatigorsk flora of the Caucasian Mineral Waters and specifically on the March flora of this region), Protokoly zasedanij Russkogo Bal neologicheskogo obshhestva v Pyatigorske, 1881-1882, pp. 47-57.

Rizenkampf A., Polny j spisok rastenij Pyatigorskoj flory (A complete list of plants of the Pyatigorsk flora), Bull. Soc. Imper. Naturalistes de Moscou, 1882, Issue XVII, No 2, pp. 222-296.

Rizenkampf A., Polny`j spisok rastenij Pyatigorskoj flory (A complete list of plants of the Pyatigorsk flora), Bull. Soc. Imper. Des Naturalistes de Moscou, 1883, Issue XVII, No 3, pp. 1-68.

Rogovsky P.A. K istorii lesnoj rastitel'nosti na pravom beregu $r$. Kubani v zone stepej (To the history of forest vegetation on the right bank of the r. Kuban in the steppe zone), Izvestiya Kubanskogo pedagogicheskogo instituta, 1928, 41 p.

Schiffers, E.V., Rastitel'nost`Severnogo Kavkaza i ego prirodny`e kormovy`e ugod'ya (Vegetation of the North Caucasus and its natural forage lands), M.-L.: Publishing House of the Academy of Sciences of the USSR, 1953, 399 p.

Shevchenko N.E., E`kologicheskie problemy` oxrany` biologicheskogo raznoobraziya gosudarstvennogo botanicheskogo zakaznika «Safonovskaya dacha» (Ecological problems of the protection of biological diversity of the state botanical reserve "Safonova dacha"), Mezhdunarodnaya konferenciya «Biologiya XXI stoletiya: teoriya, praktika, obuchenie», KievCherkasy, 2007a, pp. 356-358. 
Shevchenko N.E., Novoe mestonaxozhdenie Cephalanthera rubra (L.) Rich. (Orchidaceae Juss.) vo flore Stavropol ya i ego ontogeneticheskaya struktura (Georgievskij rajon) (New Location Cephalanthera rubra (L.) Rich. (Orchidaceae Juss.) In the flora of Stavropol and its ontogenetic structure (Georgievsky district)), 10-ya mezhdunarodnaya nauchno-prakticheskaya konferenciya «E`kologicheskie problemy`sovremennosti», Maykop, 2007b, pp. 257-258.

Shevchenko N.E., Lesa Stavropol`skoj vozvy`shennosti (Forests of the Stavropol Upland), Naukovi zapiski Derzhavnogo prirodoznavchogo muzeyu, 2008, No. 6-7, pp. 89-104.

Shevchenko N.E., Invazionny`e e`lementy` vo flore pojmenny`x lesov Central’nogo Predkavkaz'ya (Invasive elements in the flora of the floodplain forests of the Central Ciscaucasia), Problemy e`kologicheskoj bezopasnosti i soxranenie prirodno-resursnogo potenciala Materialy mezhdunarodnoj nauchno-prakticheskoj konferencii, Stavropol, 2009a. pp. 87-88.

Shevchenko N.E., Resursny`j potencial flory` pojmenny`x lesov srednego techeniya reki Kumy (Stavropol'skij kraya, Rossiya) (Resource potential of the flora of floodplain forests of the middle reaches of the Kuma River (Stavropol Territory, Russia)), Mezhdunarodnaya nauchnaya konferenciya «Biologicheskoe raznoobrazie i introdukciya rastenij», Maykop, 2009b, pp. 47-52.

Shevchenko N.E., Novy`e mestonaxozhdeniya redkix i ischezayushhix vidov rastenij vo flore Stavropol'skogo kraya. Soobshhenie 1 (New locations of rare and endangered plant species in the flora of the Stavropol Territory. Message 1), Problemy` e`kologicheskoj bezopasnosti i soxranenie prirodno-resursnogo potenciala Sbornik materialov VII Mezhdunarodnoj nauchno-prakticheskoj konferencii, Stavropol, 2011a, pp. 56-59.

Shevchenko N.E., Novy`e mestonaxozhdeniya redkix i ischezayushhix vidov rastenij vo flore Stavropol'skogo kraya. Soobshhenie 2 (New locations of rare and endangered plant species in the flora of the Stavropol Territory. Message 2), Problemy` e`kologicheskoj bezopasnosti i soxranenie prirodno-resursnogo potenciala Sbornik materialov VII Mezhdunarodnoj nauchno-prakticheskoj konferencii, Stavropol, 2011b, pp. 95-97.

Shevchenko N.E., Istoriya lesopol zovaniya pojmenny`x lesov reki Kumy (The history of forest exploitation of the Kuma River floodplain forests), Pyaty'e Prozritelevskie chteniya Materialy nauchno-prakticheskoj konferencii, $k$ 300-letiyu instituta gubernatorstva $v$ Rossii. Ministerstvo kul tury`Stavropol`skogo kraya, Stavropol`skij gosudarstvenny`j istoriko-kul turny`j $i$ prirodno-landshaftny j muzej-zapovednik im. G. N. Prozriteleva i G. K. Prave Stavropol, Stavropol, 2011c, pp. 158-159.

Shevchenko N.E., K oxrane lesov Central’nogo Predkavkaz'ya: Stavropol’skij gubernskij lesooxranitel 'ny j komitet (To the protection of the forests of the Central Ciscaucasia: Stavropol Provincial Forest Conservation Committee), Vestnik Tambovskogo universiteta. Seriya: Estestvenny `e i texnicheskie nauki, 2012, Vol. 17, No. 6, pp. 1561-1563. 
Shevchenko N.E., Lesa Central`nogo Predkavkaz’ya: floristicheskij sostav, rastitel`nost` $i$ problemy oxrany (Forests of the Central Ciscaucasia: floristic composition, vegetation and protection problems), Moscow: Moscow State Pedagogical University, 2013, 247 pp.

Shevchenko N.E., Izmenenie lesistosti i sootnosheniya glavny`x lesoobrazuyushhix vidov derev'ev $v$ lesax Central'nogo Predkavkaz'ya s koncza XVII veka po nastoyashhee vremya (Changes in the forest cover and the ratio of the main forest-forming tree species in the forests of the Central Ciscaucasia from the end of the XVII century to the present), Nauchny'e osnovy ustojchivogo upravleniya lesami Materialy`Vserossijskoj nauchnoj konferencii, Moscow, 2014, pp 94.

Shevchenko N.E., Dinamika ploshhadi i mery`sberezheniya lesov Stavropol`skoj gubernii po istoriko-geograficheskim danny'm s koncza XVII do nachala XX veka (The area dynamics and forest conservation measures of the Stavropol gubernia according to historical and geographical data from the end of the 17th to the beginning of the 20th century), Lesovedenie, 2015, No 2, pp.122-129.

Shevchenko N.E., Obzor flory` lesov Central`nogo Predkavkaz ya (Overview of the flora of forests of the Central Ciscaucasia), Voprosy` lesnoj nauki, 2018, Issue 1(1). pp. 1-17.

Shevchenko N.E. Belous V.N., Floristicheskoe $i$ fitocenoticheskoe raznoobrazie pojmennogo lesa gosudarstvennogo botanicheskogo zakaznika «Safonova dacha» (Floristic and phytocenotic diversity of the floodplain forest of the state botanical reserve "Safonova Dacha"), $X$ nauchno-prakticheskaya konferenciya «E`kologo-kraevedcheskie problemy` Stavropolya», Stavropol, 2005, 204 p.

Shevchenko N.E., Belous V.N., E`kologo-biologicheskie osobennosti $i$ rasprostranenie Trubkoczveta Bibershtejna (Solenanthus biebersteinii DC) na territorii Stavropol skogo kraya (Ecological and biological features and distribution of the Biberstein Pipeline (Solenanthus biebersteinii DC) on the territory of the Stavropol Territory), 51 nauchno - metodicheskaya konferenciya «Voprosy` fizicheskoj geografii i kraevedeniya», Stavropol, 2006, pp. 43-46.

Shevchenko N.E., Belous V.N., Osnovny`e tipy`associacij priruslovy`x lesov srednego techeniya reki Kumy` (Stavropol skij kraj) (The main types of associations of near-river forests of the middle course of the Kuma River (Stavropol Territory), E`KO: e`kologiya, krugozor, obrazovanie Staropol, Stavropol, 2007a, pp. 3-8.

Shevchenko N.E., Belous V.N., Osobennosti demograficheskoj struktury` $i$ dinamiki cenopopulyacii redkix $i$ ischezayushhix vidov Convallaria transcaucasica Utkin ex Grossh. $i$ Tulipa quercetorum Klok.et Zoz. vo flore pojmenny`x lesov srednego techeniya reki Kumy (Features of the demographic structure and dynamics of the coenopopulation of rare and endangered species of Convallaria transcaucasica Utkin ex Grossh. and Tulipa quercetorum Klok.et Zoz. in the flora of 
floodplain forests of the middle course of the Kuma River), IV Mezhdunarodnaya nauchnoprakticheskaya konferenciya «Problemy` e`kologicheskoj bezopasnosti $i$ soxranenie prirodnoresursnogo potenciala», Stavropol, 2007b, pp. 74-76.

Shevchenko N.E., Belous V.N., Biomorfologicheskij analiz flory` pojmenny`x lesov srednego techeniya reki Kumy (Stavropol'skij kraj) (Biomorphological analysis of the flora of floodplain forests of the middle reaches of the Kuma River (Stavropol Territory), VII mezhdunarodnaya nauchno-prakticheskaya konferenciya «Problemy` botaniki Yuzhnoj Sibiri $i$ Mongolii», Barnaul, 2008, pp. 17-18.

Shevchenko N.E. Belous V.N., Analiz geograficheskoj e`lementov flory` pojmenny`x lesov srednego techeniya reki Kumy (Analysis of the geographical elements of the flora of floodplain forests of the middle reaches of the Kuma River), Vos 'maya mezhdunarodnaya nauchnoprakticheskaya konferenciya «Problemy`botaniki Yuzhnoj Sibiri i Mongolii», Barnaul, 2009, pp. 144-147.

Shevchenko N.E., Belous V.N., Konspekt flory` lesov Central’nogo Predkavkazya (Summary of forest flora of the Central Ciscaucasia), Moscow-Stavropol: Paragraph, 2014, 136 p.

Shevchenko N.E., Belous V.N., Ulanovsky S.G., Paporotniki plakorny`x lesov Stavropol'skoj vozvy`shennosti (Ferns of the upland forests of the Stavropol Upland), Aktual'ny'e problemy`biologicheskoj i ximicheskoj e`kologii sbornik materialov Mezhdunarodnoj nauchnoprakticheskoj konferencii, Moscow, 2012. pp. 20-23.

Shevchenko N.E., Viktorov V.P., Lesa Central'nogo Predkavkaz'ya (Forests of the Central Ciscaucasia), Vestnik TGU, 2014. Vol. 19, No 5, pp. 1622-1625.

Shevchenko N.E., Godin V.N., Spektr polovy`x form vo flore lesov Central'nogo Predkavkaz'ya (Spectrum of sexual forms in the flora of the forests of Central Ciscaucasia), Vestnik Tomskogo gosudarstvennogo universiteta. Biologiya, 2015, No 4 (32), pp. 42-61.

Shiryaeva G., Rastitel'nost' g. Mashuk (Vegetation Mashuk), Trudy obshhestva estestvoispy`tatelej Imperatorskogo Kazanskogo universiteta, SPb., 1904, Issue XXXVII. 24 p.

Sommier S., Levier E., Enimeratio plantarum anno 1890 in Caucaso lectarum, Acta Horti Petropolitanum, 1900, Issue XVI, 568 p.

Stepunin G., Lesa Stavropol 'skoj vozvy shennosti (Forests of the Stavropol Upland), Lesnoj zhurnal, 1914, Issue 44, Vol. 8, pp. 1-16.

Steven Ch., Decas plantarum nondum descriptarum Iberiae et Rossiae meridionalis, Mem. $d$. l. Soc. Imp. d. Natur. d. Moscou, 1809. Issue II, pp. 173-183.

Tanfilyev V.G., Kononov V.N., Katalog dikorastushhix rastenij Stavropol skogo kraya. Stavropol (Catalog of wild plants of the Stavropol Territory), Stavropol, 1987, 116 p. 
Tumadzhanov I., Istoriya lesov Severnogo Kavkaza v golocene (Forest History of the North Caucasus in the Holocene), Voprosy golocena, 1961, pp. 249-266.

Umarov M.U., Taysumov M.A., Konspekt flory Chechenskoj respubliki (Abstract flora of the Chechen Republic), Grozny, 2011, 152 p.

Utenkova S.N., Flora Pyatigor`ya i eyo analiz (Pyatigorya flora and its analysis), 2001, 271 p.

Vernander T.B., Rastitel ‘nyj pokrov Beshtaugorskogo lesoparka (Vegetation cover of the Beshtaugorsky forest park), Uchyony’e zapiski Moskovskogo gosudarstvennogo universiteta, 1946, Vol. 97, pp. 99-214.

Reviewer: DSc in biology, professor Shustov M.V. 